\title{
Can we explain the trends in European ozone levels?
}

\author{
J. E. Jonson ${ }^{1}$, D. Simpson ${ }^{1}$, H. Fagerli ${ }^{1}$, and S. Solberg ${ }^{2}$ \\ ${ }^{1}$ Norwegian Meteorological Institute, Oslo, Norway \\ ${ }^{2}$ NILU, Kjeller, Norway
}

Received: 27 June 2005 - Published in Atmos. Chem. Phys. Discuss.: 15 August 2005

Revised: 8 November 2005 - Accepted: 9 December 2005 - Published: 11 January 2006

\begin{abstract}
Ozone levels in Europe are changing. Emissions of ozone precursors from Europe $\left(\mathrm{NO}_{\mathrm{x}}, \mathrm{CO}\right.$ and nonmethane hydrocarbons) have been substantially reduced over the last 10-15 years, but changes in ozone levels cannot be explained by changes in European emissions alone. The observed ozone trends at many European sites are only partially reproduced by global or regional photochemistry models, and possible reasons for this are discussed.

In order to further explain the European trends in ozone since 1990, the EMEP regional photochemistry model has been run for the years 1990 and 1995-2002. The EMEP model is a regional model centred over Europe but the model domain also includes most of the North Atlantic and the polar region. Climatological ozone data are used as initial and lateral boundary concentrations. Model results are compared to measurements over this timespan of 12 years. Possible causes for the measured trends in European surface ozone have been investigated using model sensitivity runs perturbing emissions and lateral boundary concentrations. The increase in winter ozone partially, and the decrease in the magnitude of high ozone episodes, is attributed to the decrease in ozone precursor emissions since 1990 by the model. Furthermore, the model calculations indicate that the emission reductions have resulted in a marked decrease in summer ozone in major parts of Europe, in particular in Germany. Such a trend in summer ozone is likely to be difficult to identify from the measurements alone because of large inter-annual variability.
\end{abstract}

\section{Introduction}

Both on a global/hemispheric scale, and regional/local scale, the potential to produce ozone has changed significantly af-

Correspondence to: J. E. Jonson

(j.e.jonson@met.no) ter the onset of industrialization. Both models and measurements agree that ozone levels have increased significantly over this period. As discussed below the magnitude and directions of the trends after the mid-1980s are less clear. Since the late 1980s the emissions of ozone precursors, $\mathrm{NO}_{\mathrm{x}}$, $\mathrm{CO}$ and NMVOC (non-methane volatile organic compounds) have been substantially reduced in most parts of Europe (Vestreng et al., 2004). The reduction in the emissions has resulted in corresponding reductions in the measured concentrations of these precursor species (Derwent et al., 2003; Solberg, 2004). The anticipated effect of these reductions is that ozone levels in the summer months would be reduced, and that environmentally set thresholds for ozone would be less frequently violated. Reliable surface ozone measurements are available since the late 1980s at a number of sites. However, there are large inter-annual variations in ozone levels, making it difficult to identify significant trends over the same period (see Sect. 4). The inter-annual variations are mainly determined by meteorological factors such as cloudiness, temperature and stability, affecting the ozone production and residence time in the boundary layer. Further, at many ozone sites sampling background and/or free tropospheric air, measured ozone has increased at all seasons, but in particular in winter and spring. The origin, or even extent, of this increase in European background ozone is unclear (see Sect. 4.1).

This paper discusses a number of factors which affect near-surface ozone levels over Europe, and attempts to quantify how far we can account for the observed trends in terms of European emission reductions.

\section{Factors affecting European tropospheric ozone trends}

Although not independent of each other, ozone concentrations may be viewed as the sum of a global/hemispheric background concentration and regionally/locally produced

(C) 2006 Author(s). This work is licensed under a Creative Commons License. 
Table 1. Anthropogenic Emissions (Gg/year) for the EU25 and Germany. the Czech Republic and United Kingdom separately (Vestreng et al., 2004), and from N. America (UNECE, 2004). N. America includes Canada and USA.

\begin{tabular}{lrrr}
\hline Region & \multicolumn{2}{c}{1990} \\
& $\mathrm{NO}_{\mathrm{x}}$ & $\mathrm{NMVOC}$ & $\mathrm{CO}$ \\
\hline EU 25 & 15991 & 16869 & 61213 \\
Germany & 2845 & 3591 & 11212 \\
Czech Republic & 544 & 441 & 1257 \\
United Kingdom & 2771 & 2419 & 7417 \\
N. America & 25775 & 21264 & 97651 \\
& \multicolumn{3}{c}{2002} \\
& $\mathrm{NO}_{\mathrm{x}}$ & $\mathrm{NMVOC}$ & $\mathrm{CO}$ \\
\hline EU 25 & 10988 & 10322 & 33774 \\
Germany & 1499 & 1478 & 4311 \\
Czech Republic & 318 & 203 & 546 \\
United Kingdom & 1582 & 1186 & 3238 \\
N. America & 21721 & 17790 & 111562 \\
\hline
\end{tabular}

ozone. Most of the ozone is believed to originate from the troposphere itself, but a significant fraction is also advected from the stratosphere.

The anthropogenic emissions of ozone precursors (predominantly surface sources) have changed over the last 12 decades. In Europe considerable reductions in emissions have been made since the late 1980s, as can be seen in Table 1. For $\mathrm{NO}_{\mathrm{x}}$ and NMVOC, emission reductions are of the order of $30 \%$, and for $\mathrm{CO}$ of order $45 \%$, for the $\mathrm{EU}$ as a whole, and even greater for some individual countries such as Germany where ozone precursors have been reduced by about $50 \%$.

Emissions from N. America (USA and Canada), being frequently upwind from Europe, are also given in Table 1, even though they are outside the model domain. In N. America there is a downward trend of about $15-20 \%$ for the emissions of NMVOC and $\mathrm{NO}_{\mathrm{x}}$ and a slight increase in the emissions of $\mathrm{CO}$ over the same period. Emissions are however increasing rapidly in parts of Asia (Streets et al., 2003). There is also a marked upward trend in the emissions from international shipping. Endresen et al. (2003) reports a 1.6\% per year increase in fuel consumption from shipping between 1996 and 2000.

In the individual countries changes in emissions have been achieved through different sectors. In general the dominant emission sectors have a clear seasonal variation with a winter maximum and a summer minimum. However, sector 7 (road traffic) and sector 8 (other mobile sources and machinery) have small seasonal variations, with a summer maximum. In most countries the percentage contribution from sector 7 and 8 have increased, and as a result emission reductions have been less efficient in summer than in winter. Table 2 lists the
Table 2. Percentage contribution to the national total emissions of $\mathrm{NO}_{\mathrm{x}}$ from the main sectors in 1990 and 2002 (in brackets) based on the latest available officially reported emissions.

\begin{tabular}{lrrr}
\hline Sector & Germany & Czech Republic & United Kingdom \\
\hline 1 & $22(17)$ & $43(25)$ & $32(29)$ \\
2 & $6(8)$ & $14(5)$ & $4(7)$ \\
3 & $13(12)$ & $19(11)$ & $8(11)$ \\
7 & $47(52)$ & $19(42)$ & $47(42)$ \\
8 & $10(9)$ & $3(17)$ & $8(11)$ \\
\hline
\end{tabular}

Notes: Sectors are (1) Combustion in energy and transformation industries; (2) Non-industrial combustion plants; (3) Combustion in manufacturing industry: (7) Road transport; (8) Other mobile sources and machinery.

percentage contributions to $\mathrm{NO}_{2}$ emissions in 1990 and 2002 from the dominant sectors for Germany, the Czech Republic and the United Kingdom. The United Kingdom is one of the few countries where the percentage contribution from sector 7 and 8 has decreased. In the Czech Republic the overall emissions in sector 7 and 8 have increased.

One may speculate as to what extent recent changes in the stratospheric ozone layer may have resulted in a reduction in the intrusion of ozone to the troposphere. According to Fusco and Logan (2003) the stratospheric flux of ozone into the troposphere may have decreased by as much as $30 \%$ in recent years as a result of large declines of lower stratospheric ozone. These changes should be much larger in the southern hemisphere as a result of a more pronounced decline in the ozone layer there. There are however indications that the decline in stratospheric ozone has stopped, and that stratospheric ozone started to recover in the late 1990s (Newchurch et al., 2003, 2004). As a result of global change and changes in stratospheric ozone in particular, circulation patterns may have been altered, which affects the exchange between the stratosphere and troposphere. Measured ozone at mountain tops in Europe is increasing. Kanter et al. (2004) report a pronounced rise in ${ }^{7} \mathrm{Be}$ since the mid-1970s. They argue that this is an indication, but not a proof, of an increase in the input from the stratosphere.

Boreal fires in Siberia and N. America may have a marked effect on ozone. Honrath et al. (2004) measured ozone and $\mathrm{CO}$ at Mt. Pico on the Azores, and found that ozone levels, elevated by $15 \mathrm{ppb}$ or more, could often be attributed to boreal fires. Recently it has been shown that there is a strong correlation between surface ozone (and other greenhouse gases) and large-scale biomass burning events also at Mace Head (on the Atlantic coast of Ireland) (Simmonds et al., 2005). And, as pointed out by the same authors, Canadian fires have increased steadily over the past two decades according to Stocks et al. (2003).

At least on a regional scale ozone may also be affected by changes in the circulation of the troposphere. There 
are substantial inter-annual variations in tropospheric ozone. Creilson et al. (2003) found a good correlation between the NAO (North Atlantic Oscillation) index and the tropospheric ozone column in the eastern Atlantic in spring, but not for other seasons.

\section{Trends in measured ozone precursor levels}

The EMEP assessment study showed that the reported emission changes, as discussed in the previous section, have indeed been accompanied by downward trends in the atmospheric concentrations of these species (Løvblad et al., 2004), although there are many gaps in the data. For $\mathrm{NO}_{2}$ the largest reductions in ambient concentrations at rural EMEP sites have been reported in eastern and central parts of Europe (Germany, Czech Republic), with reductions of around 50\% between 1990 and 2000. Reductions of around 30\% have been reported for $\mathrm{NO}_{2}$ for the same period in the Nordic countries, and for Italy, the Netherlands and Switzerland (Løvblad et al., 2004). It should be noted, however, that the number of regional sites with a sufficient monitoring history, and consistent set of measurement data, is rather low.

For NMVOC there is an even lower number of regionally representative monitoring sites, and the data are mostly scattered in time. The data do, however, show clear indications of reductions in NMVOC concentration levels during the 1990s (Solberg, 2004). Continuous NMVOC monitoring data from urban background sites in the UK have shown a decrease of $4.5 \% \mathrm{yr}^{-1}$ and $12 \% \mathrm{yr}^{-1}$ for individual species during 1994 2000 (Derwent et al., 2003). Thijsse et al. (1999) showed that there was a shift in the NMVOC composition at Dutch sites during 1990-1997, with an increasing aliphatic/aromatic ratio over this period. They related this change to the stronger emission reduction of aromatics caused by the increasing implementation of three-way catalysts in the vehicle fleet. Based on NMVOC measurements at the EMEP monitoring site Moerdijk, which date back to the early 1980s, Roemer (2001a) showed an excellent agreement between observed ethene and acetylene (tracers of car exhaust) and the official Dutch EMEP road traffic emissions, with an estimated reduction of the order of 50\% from 1981 to 1999. Urban studies, e.g. in Denmark (Palmgren et al., 2001), have indicated a particular strong decline in the atmospheric benzene concentration due to the reduced benzene content of petrol fuel introduced in the 1990s.

\section{Trends in measured ozone levels in the troposphere}

Trends in ozone are hard to detect because of large interannual variations, and therefore long timeseries are needed. For this reason a variety of statistical methods have been used for the meteorological adjustment of ozone trends (Kuebler et al., 2001; Brönnimann et al., 2002; TOR-2, 2003; Tarasova et al., 2004; Ordóñez et al., 2005). The measurements must be carefully checked for discontinuities and drifts in the data as discussed by Roemer (2001a). Such screening of the data can be made by visual inspection, statistical methods (Schuepbach et al., 2001) or by pairing of neighbouring sites (Roemer, 2001b). Ozone trends are expected to be different in the summer and winter seasons. It is therefore unfortunate that most trend studies analyze the measurements with regards to annual mean concentrations.

\subsection{Measured Global/Hemispheric trends}

Measurements from the early stages of industrialization indicate that ozone levels at that time may have been around $10 \mathrm{ppb}$ (Volz and Kley, 1988; Pavelin et al., 1999). There are many problems associated with these early measurements, and pre-industrial ozone levels may have been closer to $20 \mathrm{ppbv}$ as measured at Arosa in the 1950s (Staehelin et al., 1994). Studies of ozone-sonde data in the free troposphere (Logan, 1994; Logan et al., 1999; Oltmans et al., 1998) point to a general increase in free tropospheric ozone up to the mid 1980s, and then a mixed picture with many sites/regions showing no significant trend, or even negative trends, after that. In WMO (2002) trends have been calculated including 4 more years (1996-2000), but these additional 4 years did not alter the conclusions significantly. Naja et al. (2003) studied ozone trends at Hohenpeissenberg and Payern and found no positive trends for background ozone in the free troposphere.

Studying trends in the last decade at different altitudes in Switzerland, Ordóñez et al. (2004) found a statistically significant trend of $0.2-0.7 \mathrm{ppb} \mathrm{yr}^{-1}$ at elevated sites from autumn to spring, at a time when these stations are predominantly measuring free tropospheric air. One of the sites (Jungfraujoch, $3580 \mathrm{~m}$ a.s.l.) is located close to the ozone sonde station Payern, where no significant trend was reported at this height (Naja et al., 2003). At Zugspitze, $2962 \mathrm{~m}$ a.s.l., there is a positive ozone trend between 1990 and 2001, whereas at the nearby, but about $1000 \mathrm{~m}$ lower in altitude, site Wank which is more influenced by local effects, there is no significant trend (Kanter et al., 2004).

In the MOZAIC project (http://www.aero.obs-mip.fr/ mozaic/) tropospheric ozone has been measured on a routine basis on commercial aircrafts since 1994. Above Frankfurt and Paris the MOZAIC data indicate trends ranging from about $1.7 \% \mathrm{yr}^{-1}$ in winter to virtually zero in summer (Zbinden et al., 2005). However, the trend is affected by a high anomaly in 1997-1999 of about 10\%. It is unclear as to what extent the trend reported at elevated sites are affected by the same anomaly. Over western Europe and the eastern Atlantic the high ozone levels in the free troposphere in springtime are correlated with the NAO index in the late 1990s as noted in Sect. 2.

Analysis of the clean sector at surface sites measuring relatively unpolluted airmasses (British Isles, Scandinavia) show that there has been an increase in background ozone levels also after the mid 1980s for all seasons, although the increase 
is strongest in winter (Solberg, 2003; Roemer, 2001a). Simmonds et al. (2004) found that background ozone in the clean oceanic sector measured at Mace Head, Ireland has increased by about 8 ppb from 1987 to 2003 .

The difference in trends between the ozone sondes and other measurements such as the MOZAIC data, Mace Head, and mountain sites which often sample free tropospheric air, are not easily reconciled. According to Ordóñez (personal communication) the inconsistency in the trends for sondes versus other measurements may be related to the low sensitivity and very low time resolution of these ozone sonde measurements. There may also have been a change in the meteorological limitations as to when to make soundings.

It is unlikely that the increase in ozone in the Atlantic sector at Mace Head (and other surface sites measuring background ozone) is confined to the boundary layer alone, as emissions of ozone precursors have decreased at both sides of the Atlantic. As will be discussed in Sect. 5, this strongly suggests that the increase results from an increase in the free troposphere.

\subsection{Measured ozone trends in Europe}

Trend analysis of ozone measurements have been mainly restricted to northern and western parts of Europe, where routine measurement of ozone first started, and where timeseries are long enough to perform meaningful studies. Overviews of reported trends are given in several publications (Roemer, 2001a; TOR-2, 2003; Monks et al., 2003; Solberg et al., 2004). Apart from background sites on the western coast of Europe, trends in surface ozone do not show a uniform picture. However, most sites show substantial downward trends of high ozone (98 or 95 percentiles) over the past 10 to 15 years. For example, in the UK peak ozone concentrations have decreased by about 30\% in the period 1986-2001 whilst annual average ozone levels have increased slightly (NEGTAP, 2001). According to Beilke and Wilson (2000), studying the trend at more than 300 ozone sites in Germany between 1990 and 2000, the 99 percentile dropped by $3.3 \mu \mathrm{g}$ per year (ca. $1.6 \mathrm{ppb} \mathrm{yr}^{-1}$ ), but with no significant trend for the ozone indicator AOT40, which is a measure of longerterm ozone values (see, e.g. Fuhrer et al., 1997, for definition of AOT40).

Furthermore, at most polluted sites the low ozone percentiles (mainly winter) are increasing. An important contribution to this upward trend is a reduction in the titration by $\mathrm{O}_{3}+\mathrm{NO}$ reaction in response to the reduction in $\mathrm{NO}_{\mathrm{x}}$ emissions.

\section{Calculated trends}

\subsection{Results from other studies}

Model calculations indicate that there has been a substantial increase in tropospheric ozone since pre-industrial times, and that the increase in global free tropospheric ozone has contributed to the increase in surface ozone also in Europe (Berntsen et al., 1997; Lelieveld and Dentener, 2000; Karlsdottir et al., 2000; Hauglustaine and Brasseur, 2001). Fusco and Logan (2003) performed model simulations from 1970 to 1994 , and found increasing ozone levels, which they attributed to increasing emissions worldwide. In addition to future projections, Dentener et al. (2004), in a transient global model calculation, compared measured and modeled ozone for 6 surface sites, of which 3 (Westerland, Brotjacklriegel and Schauinsland) are in Europe. None of the sites showed significant measured or calculated trends. Both Brotjacklriegel and Schauinsland are located at some distance from the coast, and calculated and measured trends should be influenced by a combination of background and regional ozone.

Among the global model calculations reported above there is thus a considerable spread in the calculated trend for ozone.

Substantial reductions in modeled peak ozone levels were found comparing results from ten European dispersion models in response to emission changes during the 1990s (Roemer et al., 2003). A positive trend in winter ozone, mostly in the 2-4 ppb range in central Europe, was also seen in the model results. This is in good agreement with measurements as noted in Sect. 4.2. Following the decrease in the emissions of ozone precursors, model calculated mean ozone also decreased in summer by about $10 \%$, but with substantial variability between models. This decrease is not confirmed by the analysis of the measurements. Similar model results were also obtained as part of the EU project TROTREP (Monks et al., 2003). Here particularly large reductions in mean summer ozone were calculated for eastern Europe. In this region there are insufficient measurement data available to verify the model results. In Solberg et al. (2005) it was shown that the changes in the European emissions of ozone precursors in the 1990s have led to significant reductions in measured and calculated surface ozone episodes in the Nordic countries.

As already noted, emissions from international shipping have been increasing at an annual rate of about $1.6 \%$ in recent years. International shipping has been shown to result in a calculated perturbation of more than $10 \mathrm{ppb}$ in the North Atlantic in the summer (Jonson et al., 2000b; Endresen et al., 2003), with the largest perturbation in the mid Atlantic where $\mathrm{NO}_{\mathrm{x}}$ levels are in general low. Calculated effects of international shipping over the European continent are small (Jonson et al., 2000b). Such calculations of the effects of ship emissions are however likely to be overestimates because of the non-linearities involved in modeling in low- $\mathrm{NO}_{\mathrm{x}}$ oceanic areas (Davis et al., 2001; von Glasow et al., 2003). Thus the trend for this source can probably not explain the increase in surface ozone in the clean oceanic sites such as Mace Head, or the increase at mountain tops, mostly in the free troposphere, in winter.

In east Asia ozone and ozone precursors have a greater chance of being lifted into the free troposphere by convection 
compared to other polluted continents, and thereby contribute to an increasing trend in the free troposphere throughout the northern mid latitudes. Several studies have tried to quantify the contributions to the ozone levels from different continents or source regions. Derwent et al. (2004) studied the effects of inter-continental transport on ozone by a labeling technique and by separately reducing the anthropogenic emissions in N. America, Europe and Asia of $\mathrm{NO}_{\mathrm{x}}$ and $\mathrm{CO}$ by $50 \%$ on an annual basis. The labelling technique indicated a contribution of more than $8 \mathrm{ppb}$ from N. America and $4.5 \mathrm{ppb}$ from Asia. Because of non-linearities in the ozone chemistry the tracer labeling technique gives a much higher estimate for the inter-continental contribution than with a $50 \%$ reduction in $\mathrm{NO}_{\mathrm{x}}$ and $\mathrm{CO}$ emissions from $\mathrm{N}$. America and Asia. In a similar study by $\mathrm{Li}$ et al. (2002) sources in N. America and Asia were separately completely shut off. For the summer months (June, July, August) the calculated contribution from N. America to western parts of Europe by $\mathrm{Li}$ et al. (2002) was of the order of $2-3 \mathrm{ppb}$, whereas the contribution from Asia was of the order of $1 \mathrm{ppb}$. The effect of inter-continental transport is expected to be relatively smaller in summer. The annual contribution should therefore be larger than just the summer season as studied by Li et al. (2002). Keeping in mind that in the latter study emissions were completely shut off, whereas in Derwent et al. (2004) sources were reduced by $50 \%$, the corresponding results are similar in magnitude.

From the model calculations cited above it seems that the measured increase in background ozone indicated by measurements at Mace Head and mountain tops can only be partially explained by emission changes in other continents or from international shipping.

\subsection{Description of the EMEP model}

The EMEP Eulerian Photochemistry model has a polar stereographic projection with a horizontal resolution of $50 \times 50 \mathrm{~km}^{2}$ true at $60^{\circ} \mathrm{N}$ and 20 vertical layers below $100 \mathrm{hPa}$. The model domain is centered over Europe and also includes most of the North Atlantic and the polar region. The EMEP model uses 3-hourly resolution meteorological input data from a dedicated version of the HIRLAM model. The emission data for individual years have been retrieved from the EMEP database (Vestreng et al., 2004). Emissions are distributed temporarily and vertically depending on source category. Emissions of $\mathrm{NO}_{\mathrm{x}}$ and $\mathrm{SO}_{2}$ from international shipping have been assumed to increase by $2.5 \% \mathrm{yr}^{-1}$ from 1990 to 2002. Descriptions and applications of earlier versions of the model can be found in Berge and Jakobsen (1998) and Jonson et al. (1998, 2000a, 2001). Compared to earlier model versions the chemical mechanism is now based on the "EMEP scheme" previously described in Simpson et al. (1993); Simpson (1995) and Andersson-Sköld and Simpson (1999), but with additional reactions introduced to extend the coverage to acidification and eutrophication issues. The chemical equations are now solved using the TWOSTEP algorithm tested by Verwer and Simpson (1995). The dry deposition scheme has also been updated. Details of the dry deposition module are given in Simpson et al. (2003a). For ozone the methods have been extensively described in a series of articles (Emberson et al., 2000, 2001; Simpson et al., 2001, 2003b; Tuovinen et al., 2001, 2004). A thorough description of the model is included in Simpson et al. (2003a), with updates reported in Fagerli et al. (2004).

Initial and lateral boundary conditions (BCs), especially of ozone, represent key inputs to the EMEP model. For ozone, these boundary conditions are derived from the 3-D ozone climatology of Logan (1999), modified in order to accommodate inter-annual variabilities in air masses arriving from the upwind Atlantic region. The modifications are based on the measurements at Mace Head, Ireland as described in Simpson et al. (2003a), filtered using trajectory analysis to obtain clean-sector $\mathrm{O}_{3}$ values. The adjustment (in ppb ozone) in lateral boundary concentrations is the same for the whole model domain and at all vertical levels. As ozone mixing ratios generally increase with altitude, the relative adjustment is largest near the surface and becomes very small in the upper free troposphere. This procedure was chosen since data from Mace Head cannot in principal be used to correct mid- to uppertropospheric ozone, and in any case a marked trend is not evident from free tropospheric ozone sonde measurements (see Sect. 4.1). The assumption that all lateral boundaries are affected equally by the Mace Head adjustment is rather crude, but works well because the main bulk of the model domain is subject primarily to dominating westerly air movements. The motivation for and effects of the Mace Head correction will be discussed in more detail in a separate paper.

Lateral boundary concentrations are specified for $\mathrm{SO}_{2}$, $\mathrm{SO}_{4}, \mathrm{NO}, \mathrm{NO}_{2}$ PAN, $\mathrm{HNO}_{3}, \mathrm{CO}$, and some VOCs. Concentrations are specified by annual mean concentrations and a set of parameters for each species describing seasonal, latitudinal and vertical, distributions. The lateral boundary concentrations are taken from a variety of sources described in more detail in Simpson et al. (2003a). In addition we assume trends for $\mathrm{NO}_{\mathrm{x}}$ and $\mathrm{SO}_{2}$ based on emissions from EPA.

\subsection{Model runs and sensitivity tests}

To explain the mechanisms behind the trends in European ozone (and $\mathrm{NO}_{2}$ ) levels, we make use of three set of models calculations:

\section{- RefYYYY:}

For a year YYYY, emissions from YYYY, meteorology from YYYY, and monthly ozone boundary conditions also for YYYY, through the Mace Head correction. Ref2002 (with YYYY as 2002) is the reference case against which sensitivity tests are conducted.

- Em1990:

Emissions from 1990, meteorology from 2002, and 


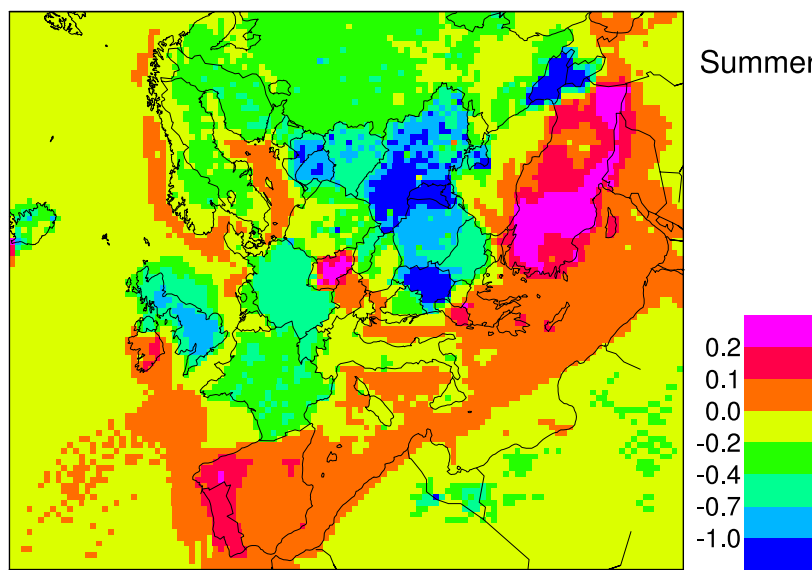

a) Diff. summer $\mathrm{NO}_{2}$ concentrations 1-Em1990/Ref2002

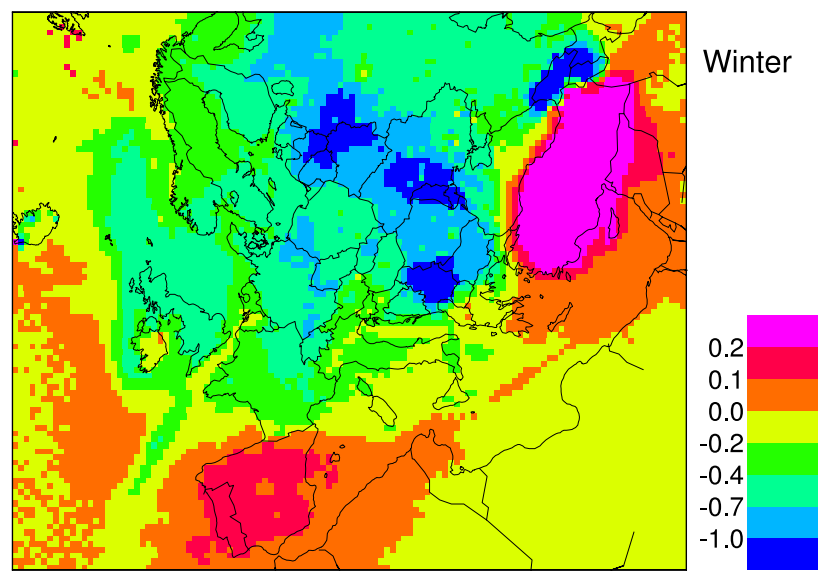

b) Diff. winter $\mathrm{NO}_{2}$ concentrations 1-Em1990/Ref2002

Fig. 1. Fractional difference in calculated $\mathrm{NO}_{2}$ concentrations in (a) summer and (b) winter. Ref2002 is the reference model run. Em1990 is the same model run repeated with 1990 emissions.

monthly ozone boundary conditions also for 2002, through the Mace Head correction. (Same as Ref2002, except for emissions)

- AvgBC:

Emissions from 2002, meteorology from 2002, and the same monthly ozone boundary conditions each year, which consist of a "10-year" climatology based upon the monthly averages of the data-sets over the period 1990-2000. (Same as Ref2002, except for BCs)

The "Ref" runs corresponds to normal EMEP model usage and represents our best estimate of emissions, meteorology and BCs. The Em1990 case is used to explore the effect of emission changes only. The AvgBC case is used to explore what happens when interannual variability and trends are ignored. (The AvgBCs where chosen rather than 1990 BCs as this is more robust than BCs from a single year. )
For the "Ref" series of runs, model calculations with the EMEP photochemistry model have been made for 1990 and for the years 1995 to 2002. The years 1991-1994 are not included in the calculations as we have no meteorological input data for these years. Emissions for the relevant years are from Vestreng et al. (2004).

5.4 Calculated and measured $\mathrm{NO}_{2}$ in the European boundary layer, 1990 to 2002

In Fig. 1 the differences in calculated $\mathrm{NO}_{2}$ concentrations are shown for a) summer and b) winter. In winter (January, February) calculated reductions in $\mathrm{NO}_{2}$ are of the order of $30 \%$ or more in central and eastern Europe. In summer (June, July, August) reductions are in general smaller, and in some areas such as in Hungary and in particular the Czech Republic, absent or even positive. In the Iberian peninsula and in Turkey $\mathrm{NO}_{\mathrm{x}}$ emissions have increased, resulting in higher concentrations. Concentrations have also increased over many ocean areas, consistent with increasing ship emissions over this period.

The $\mathrm{NO}_{2}$ measurements used in this paper are daily samples using either absorbing solution (Germany, Poland) or NaI impregnated glass sinters (Sweden, Norway, Hungary). Both of these methods are more selective for $\mathrm{NO}_{2}$ than the standard $\mathrm{NO}_{\mathrm{x}}$ monitor. There can be some interference with $\mathrm{HNO}_{2}$, but the concentration level of this compound is expected to be relatively low. Unfortunately, there is a clear bias towards northwest Europe in the location of the sites, so we cannot evaluate changes in many other parts of Europe.

Figure 2 depicts measured and calculated $\mathrm{NO}_{2}$ levels for 13 European sites measuring $\mathrm{NO}_{2}$ for all relevant years, for (a) the ensemble of all 13 sites, (b) the 3 German sites, (c) the 8 northern European sites, and (d) the 2 eastern European sites. There is a tendency for the model to overpredict winter concentrations especially in the Nordic areas, and to underpredict summer concentrations of $\mathrm{NO}_{2}$, but in general the levels and seasonal patterns of $\mathrm{NO}_{2}$ are well captured by the model. Trends for the same site ensembles as in Fig. 2, and for the 13 individual sites, are listed for all 4 seasons in Table 3. As for the model calculations, measured trends are derived disregarding the years 1991-1994. In general the measured trends are reasonably well reproduced by the model. However, both calculated and measured trends may be biased by the use of only one year (1990) at the beginning of the period. Observed wintertime $\mathrm{NO}_{2}$ seems to have decreased by $1-2 \mu \mathrm{g} \mathrm{Nm}^{-3}$ over the European stations from 1990 to 2000, but less in northern Europe, where levels are much lower. As in Fig. 1, summertime trends are smaller, and in some areas even absent both for measured and calculated $\mathrm{NO}_{2}$. The small calculated trends in northern Europe can partially be attributed to the assumed increase in emissions from international shipping, which represent a significant fraction of $\mathrm{NO}_{\mathrm{x}}$ emissions in that region. 

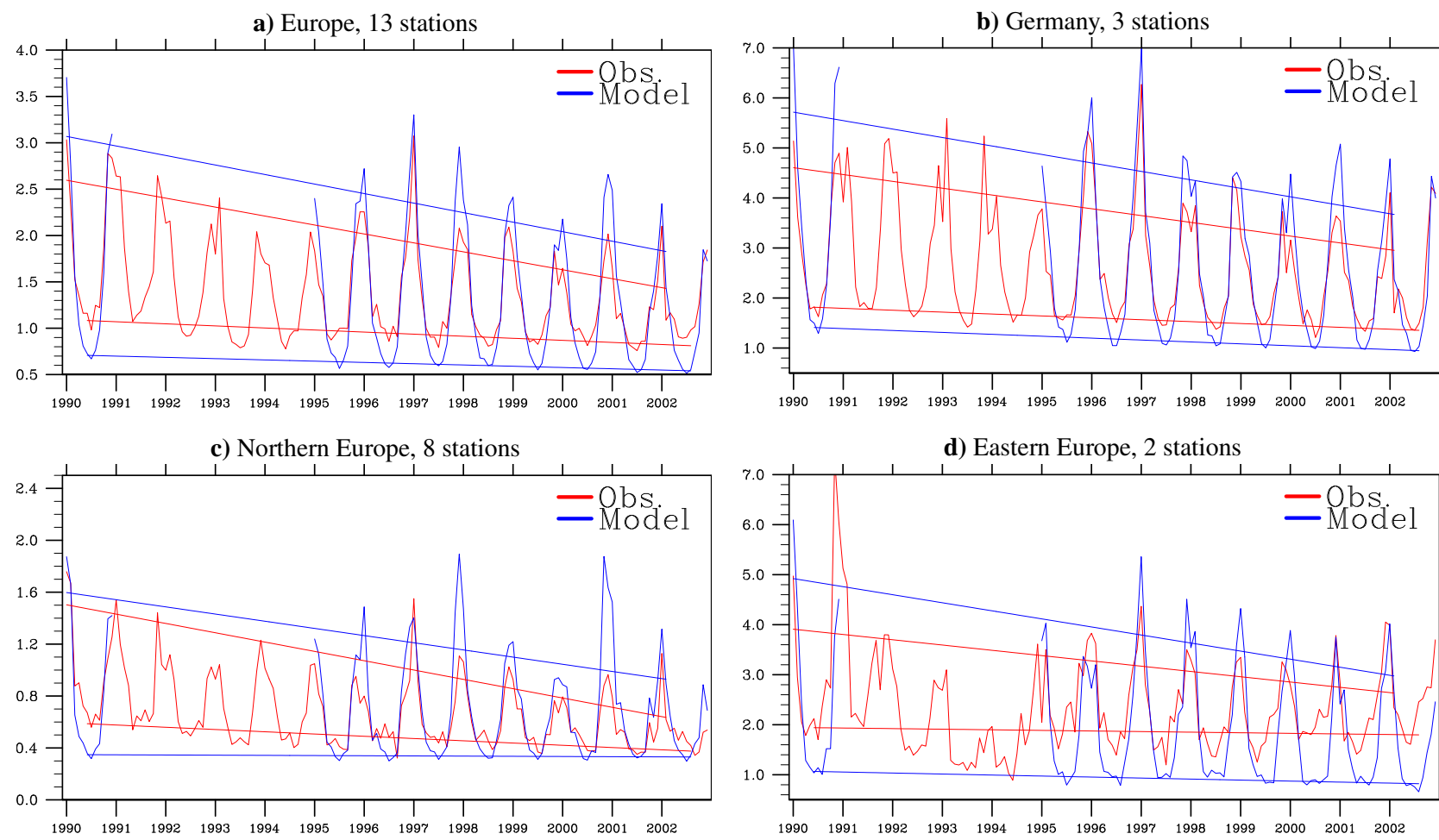

Fig. 2. Measured and model calculated $\mathrm{NO}_{2}$ in $\mu \mathrm{g}(\mathrm{N}) \mathrm{m}^{-3}$ for the sites (Westerland DE01, Deuselbach DE04, Langenbrügge DE02, Hoburg SE08, Bredkälen SE05, Vavihill SE11, Osen NO41, Kårvatn NO39, Tustervatn NO15, Skreådalen NO08, Birkenes NO01, Jarczew PL02, Kpuszta HU02) upper left, for the 3 German sites (Westerland, Deuselbach, Langenbrügge), upper right, for the Swedish (Hoburg, Bredkälen, Vavihill) and Norwegian sites (Osen, Kårvatn, Tustervatn, Skreådalen, Birkenes) lower left, and the 2 Eastern European sites (Jarczew in Poland and K-puszta in Hungary) lower right. In addition summer and winter trends are shown as straight lines. The years 1991-1994 have not been used deriving the measured trend.

A likely explanation for the smaller measured and calculated reductions in $\mathrm{NO}_{2}$ in summer, and the calculated increase in the Czech Republic as shown in Fig. 1a in particular, is that emissions from stationary sources, peaking in winter, have decreased whereas changes in mobile sources (sector 7 and 8, see Table 2), with virtually constant emissions throughout the year, are smaller, and in some areas even positive.

Overall the decrease in annual $\mathrm{NO}_{2}$ levels is consistent with the emission reductions summarized in Table 1. This is in good agreement with other studies as reported in Sect. 3 .

\subsection{Calculated ozone over Europe for the years 1990 to 2002}

In large parts of Europe the emissions of ozone precursors peaked in the late 1980s. A substantial number of reliable measurements for trend studies are available from about the same time, and we have been able to make use of 54 EMEP sites which had continuous measurements over these years. As already noted in Sect. 4 the interpretation of measured trends are not straight forward. To avoid some of the prob- lems related to the individual sites we mainly base our conclusions from the model to measurement comparisons on ensembles of sites. Figure 3 illustrates calculated and measured monthly averaged daily maximum ozone for (a) all 54 sites, (b) the northern European sites (Norway, Sweden and Finland), (c) the German sites, and (d) Ispra (IT04, Italy, the only site with continuous measurements for all the years found for southern Europe), (e) Mace Head (IE31, Ireland), and (f) Deuselbach, (Germany, DE04). No representative sites were found for eastern Europe. In the same figure panels we also show the summer and winter linear trends. Measured and calculated trends for all 4 seasons are listed for several sites (including the ensembles/sites shown in Fig. 3) in Table 4. As for the model calculations, measured trends are derived disregarding the years 1991-1994. As for $\mathrm{NO}_{2}$ calculated and measured trends may be biased by the use of a single year (1990) at the beginning of the period. The inter-annual variability of ozone from the measurements is well reproduced by the model, with very good agreement for the ensemble of 54 stations, and for Germany in particular. Poorest results are seen for northern Europe, where there is a tendency for the model to under-predict spring ozone. In most areas and 
Table 3. Measured and model calculated seasonal $\mathrm{NO}_{2}$ trends in $\mu \mathrm{g}(\mathrm{N}) \mathrm{m}^{-3} / \mathrm{yr}$ for the sites/site ensembles shown in Fig. 2 . For winter (January, February) and summer (June, July, August) the linear trends listed below are also shown in the same figure. Spring includes data for March, April and May, whereas autumn includes the months September, October and November.

\begin{tabular}{|c|c|c|c|c|c|c|c|c|}
\hline \multirow[b]{2}{*}{ Ensemble/site } & \multicolumn{2}{|c|}{$\begin{array}{c}\text { Winter } \\
\text { (January, February) }\end{array}$} & \multicolumn{2}{|c|}{$\begin{array}{c}\text { Spring } \\
\text { (March, April, May) }\end{array}$} & \multicolumn{2}{|c|}{$\begin{array}{c}\text { Summer } \\
\text { (June, July, August) }\end{array}$} & \multicolumn{2}{|c|}{$\begin{array}{c}\text { Autumn } \\
\text { (September, October, November) }\end{array}$} \\
\hline & Measured & Modeled & Measured & Modeled & Measured & Modeled & Measured & Modeled \\
\hline Europe (Fig. 2a) & -3.72 & -3.35 & -1.98 & -1.72 & -2.04 & -1.92 & -3.17 & -2.94 \\
\hline North Europe (Fig. 2c) & -4.78 & -3.46 & -3.18 & 0.00 & -2.92 & -0.41 & -3.91 & -1.88 \\
\hline SE05 (63.51 N, 15.20E) & -5.89 & -4.31 & -1.90 & -0.10 & -3.78 & -1.14 & -3.78 & 1.81 \\
\hline SE08 (56.55 N, 18.09E) & -3.90 & -2.57 & 3.31 & 1.48 & 1.17 & 1.72 & -1.09 & -2.02 \\
\hline SE11 (56.01 N, 13.09E) & -3.80 & -2.71 & -2.38 & -1.43 & -3.22 & -1.51 & -3.37 & -2.76 \\
\hline NO01 (58.23 N, 8.15E) & -5.89 & -4.47 & -5.32 & 3.42 & -4.03 & 0.42 & -5.09 & -1.98 \\
\hline NO08 (58.49 N, 6.43 E) & -6.27 & -3.98 & -4.72 & -0.31 & -2.34 & -0.73 & -5.15 & -2.15 \\
\hline $\mathrm{NO} 15(65.50 \mathrm{~N}, 13.55 \mathrm{E})$ & -7.89 & -4.08 & -7.03 & -0.70 & -5.02 & -0.63 & -7.14 & 2.60 \\
\hline NO39 (62.47 N, $8.53 \mathrm{E})$ & -4.88 & -4.22 & -7.14 & 0.01 & -4.71 & -1.11 & -5.02 & -1.51 \\
\hline NO41 (61.15 N, 11.47 E) & -4.57 & -4.79 & -4.35 & 0.12 & -3.77 & -1.04 & -4.27 & 0.01 \\
\hline Germany (Fig. 2b) & -2.97 & -2.96 & -1.55 & -2.22 & -2.07 & -2.67 & -2.27 & -3.20 \\
\hline DE01 (54.56N, 8.19E) & -3.06 & -3.42 & -1.08 & 0.29 & -1.14 & -0.53 & -1.67 & -2.46 \\
\hline DE02 (52.48 N, 10.45E) & -3.07 & -3.24 & -1.94 & -2.83 & -2.52 & -3.26 & -1.78 & -3.53 \\
\hline DE04 (49.46N, 7.03 E) & -2.53 & -2.03 & -1.60 & -2.90 & -2.19 & -3.16 & -2.63 & -3.17 \\
\hline East Europe (Fig. 2d) & -2.70 & -3.27 & -0.95 & -2.77 & -0.61 & -1.88 & -3.47 & -3.19 \\
\hline PL02 (51.19N, 21.59E) & -2.45 & -2.96 & -2.41 & -2.86 & -0.71 & -2.71 & -1.65 & -3.93 \\
\hline HU02 (46.58 N, 19.35E) & -0.85 & -2.99 & 2.81 & -2.68 & -0.40 & -0.97 & -6.15 & -2.85 \\
\hline
\end{tabular}

seasons there is very little apparent drift in the model bias over the years (Exceptions are some of the UK sites and Ispra in northern Italy as discussed in Sect. 5.5.1).

Trends in tropospheric ozone are closely linked to the seasonal cycle of ozone. Clean unpolluted sites have a spring ozone maximum and a summer minimum (Monks et al., 2003), whereas polluted (continental) sites are characterized by a broad summer maximum. In particular Mace Head (Fig. 3e), but also the northern European sites (Fig. 3b), are gradually behaving more like unpolluted background sites. At Mace Head the summer and winter trend lines have crossed, resulting in a summer minimum for ozone. In northern Europe they are likely to cross in the near future. For both figures spring ozone is seen as the annual peak above the trend lines.

The European ensemble (Fig. 3a and the European ensemble in Table 4) seems to confirm the conclusions from the trend studies already discussed in Sect. 4.2, with ozone levels increasing in winter and less clear or mixed trends in mean ozone for other seasons. Calculated trends and measured trends for different seasons and regions are discussed in more detail below.

\subsubsection{Em1990 scenario: effects on summer ozone}

Figure 4a shows mean summer (June, July, August) daily maximum ozone for the base-case simulation for the year 2002 (Ref2002). High ozone levels are in particular seen over the Mediterranean ocean and in northern Italy. Relatively high summer ozone is also seen in southern parts of Germany and neighbouring countries.

Figure $4 \mathrm{~b}$ shows the difference in mean summer ozone levels obtained when using present (year 2002) emissions compared to when using 1990 emissions for the same meteorological year (2002). Throughout major parts of Europe calculated ozone reductions are in the 5-10 ppb range. Over Turkey and the Iberian peninsula emissions of ozone precursors have increased (Vestreng et al., 2004), resulting in small changes or a slight increase in calculated ozone here.

In central Europe, Fig. 4b shows substantial reductions in calculated summer ozone as a result of the Em1990 scenario. In southern Germany in particular, reductions in calculated ozone of more than $12 \mathrm{ppb}$ are predicted. The reductions reflect the substantial reductions in the emissions of ozone precursors in most of Europe, and in particular in Germany, in the same period. However, these ozone reductions are greater than those found in the observations or in the base-case ("Ref") series of model runs for the German sites (Figs. 3c, f, Table 4). 

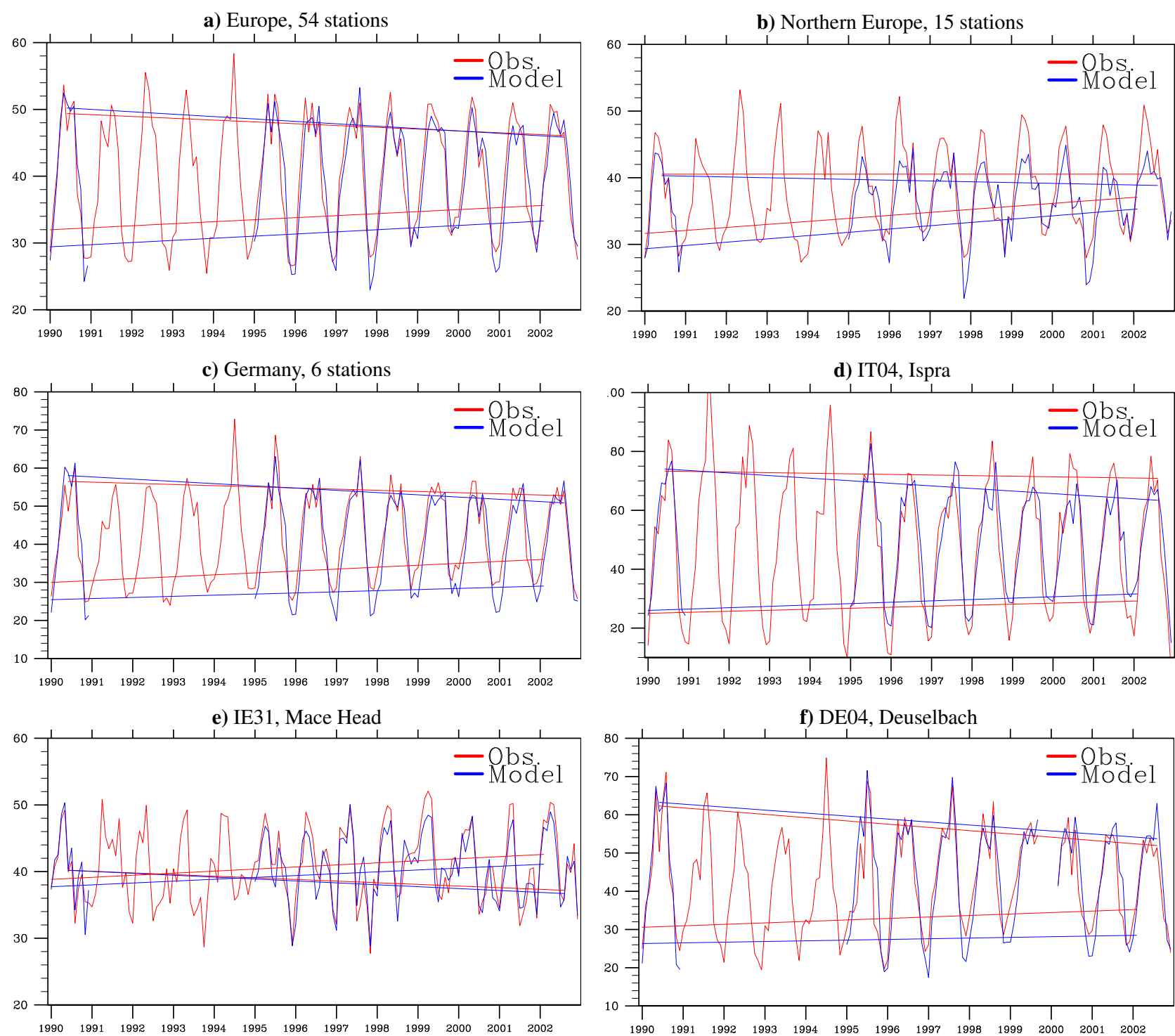

Fig. 3. Measured and model calculated monthly averaged ozone in ppb. In addition summer and winter trends are shown as straight lines. For all sites except Mace Head the summer trend lines lies above the winter lines. At Mace Head the trend lines cross and winter ozone is higher than summer ozone for the latter part of the figure. The years 1991-1994 have not been used deriving the measured trend. The top left panel show all sites with continuous ozone measurements for all relevant years, Top right the N. European subset of sites, middle left the German sites, Ispra in N. Italy (middle right), Mace Head (bottom left) and Deuselbach (bottom right). See also Table 4.

In the UK and Ireland there is a marked difference in model bias from north to south. For Mace Head (IE31) and Strath Vaich Dam (GB15) modeled and measured trends are comparable, whereas for the sites further south there are large negative trends measured, in particular for summer ozone. Measured summer trends in southern parts of the UK are comparable to trends in Germany. This is only partially reproduced by the model.

For the northern Mediterranean area, the Em1990 scenario predicts an ozone reduction of ca. 6-12 ppb. This change is similar to that predicted in the "Ref" series of runs
( $0.87 \mathrm{ppb} \mathrm{yr}^{-1}$ for Ispra), but much greater than the observed trend $\left(0.2 \mathrm{ppb} \mathrm{yr}^{-1}\right.$, Table 4). Results from one site need to be interpreted with caution, so the main conclusion from this study is that for this region the emission trends account for most of the change in modeled ozone between 1990 and 2002.

For the Nordic areas, the Em1990 scenario predicts an ozone reduction of ca. 0-6 ppb. As shown in Fig. $3 b$ and in Table 4 there is virtually no summer trend in this region in either the "Ref"-series of runs or the measurements. As the "Ref"-series include the effects of both emission changes 
Table 4. Measured and model calculated seasonal $\mathrm{O}_{3}$ trends in ppb/yr for the sites/site ensembles shown in Fig. 3. For winter (January, February) and summer (June, July, August) trends the linear trends are also shown in the same figure. Spring includes data for March, April and May, whereas autumn includes the months September, October and November. The European ensemble are made up of 13 sites in Great Britain, 11 Austrian sites, 8 Norwegian sites, 6 German sites, 4 Swedish sites, 3 Finnish sites, 2 Belgian sites, 2 Swiss sites and one site in Ireland, Denmark, The Netherlands, Portugal and Italy. N. Europe are made up of a subset of the Norwegian, Swedish and Finnish sites.

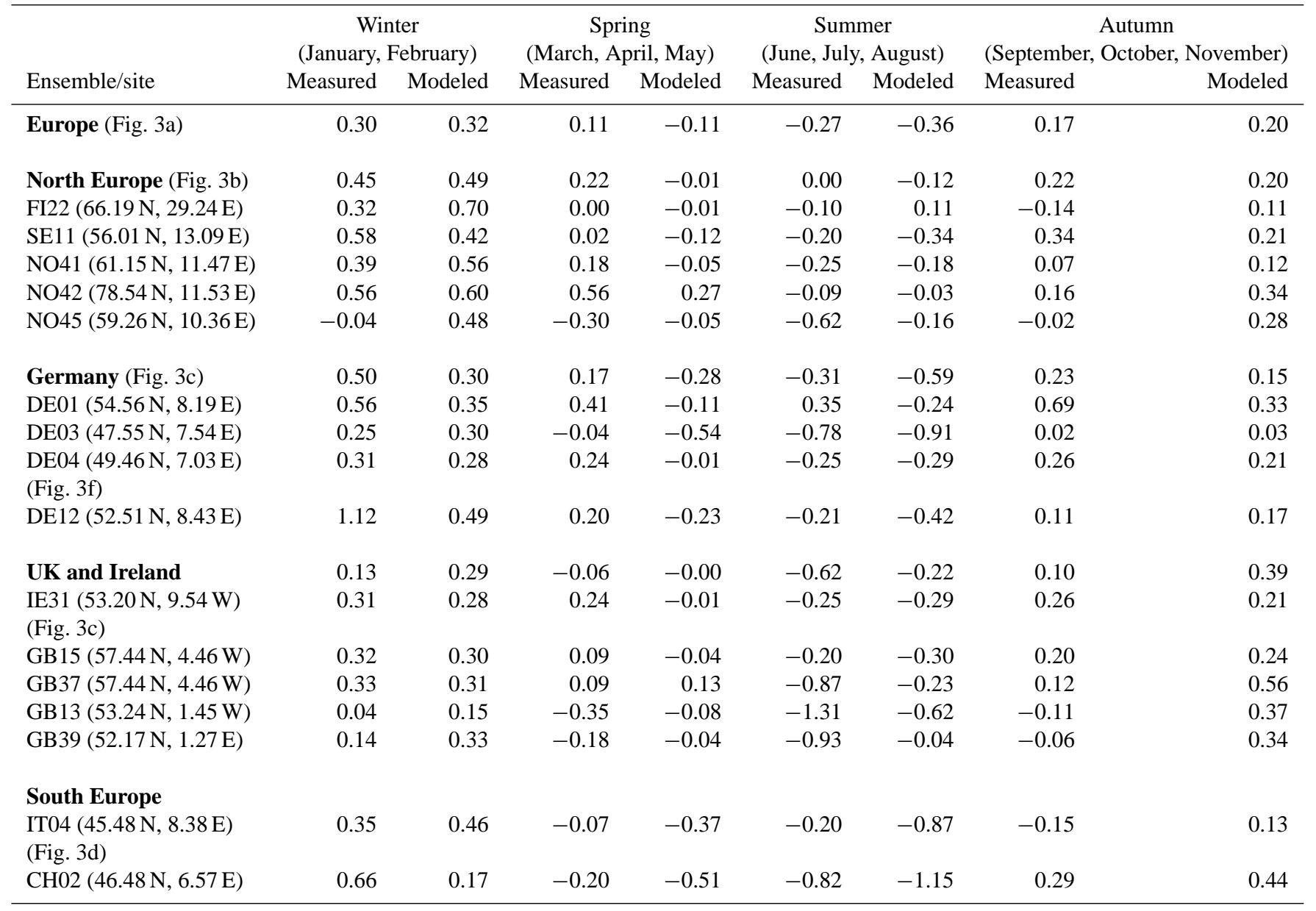

and $\mathrm{BC}$ changes, it seems clear that the effect of the emission reduction seen in Fig. $4 \mathrm{~b}$ has been canceled out by the changes in BCs.

\subsubsection{Em1990 Scenario: effects on winter ozone}

In winter ozone levels are low over the European continent (Fig. 5a), largely as a result of the titration reaction $\mathrm{NO}+\mathrm{O}_{3} \rightarrow \mathrm{NO}_{2}+\mathrm{O}_{2}$ and the lack of photochemical activity in most areas. As seen in Fig. 5b, the decrease in $\mathrm{NO}_{\mathrm{x}}$, NMVOC (and other ozone precursors) emissions associated with the Em1990 scenario should have resulted in an increase in ozone levels of the order of $2 \mathrm{ppb}$ or more in most parts of central Europe. This change is in the same range as the "Ref"-series of runs, and the observations, as given in Fig. 3c and in Table 4, demonstrating that increases caused by changes in emissions are comparable to increases from $\mathrm{BCs}$ in central Europe.

Over northern Italy, the Em1990 scenario is predicted to result in ozone increases of around $0-2 \mathrm{ppb}$. This is less than the trends predicted by the "Ref" series of runs, or found in the observations (Fig. 3, Table 4). Results for the Nordic areas are very similar. The Em1990 scenario results in ozone increases of around $0-2 \mathrm{ppb}$, which is again less than the trends predicted by the "Ref" series of runs, or the observations. These results suggest that in both of these regions both emissions and BCs play a role in determining the wintertime ozone changes. 


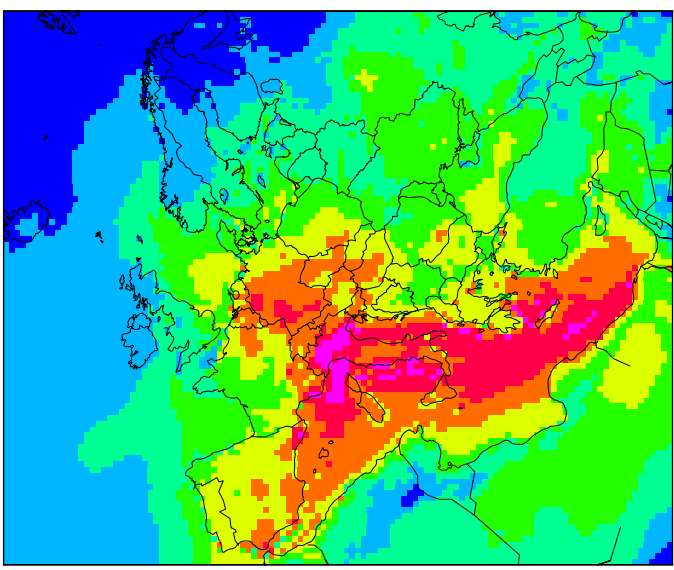

(a) Summer (June, July, August) daily max. ozone (ppb)

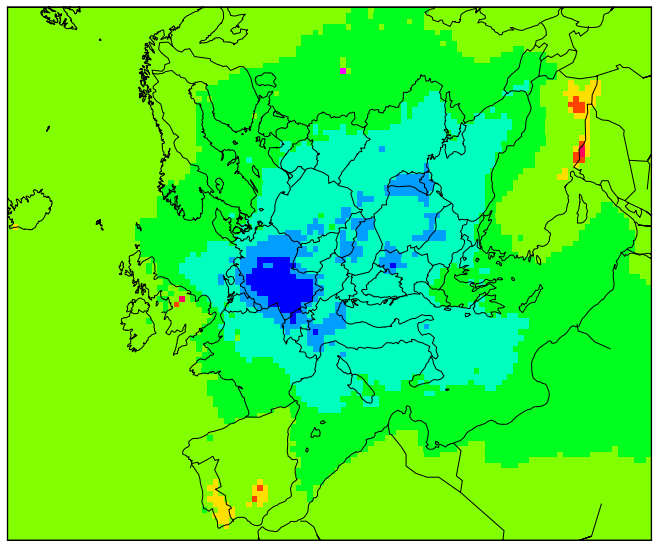

2002

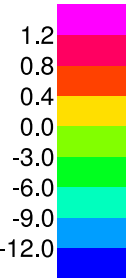

(b) Summer daily max. ozone (ppb), diff. Ref2002-Em1990

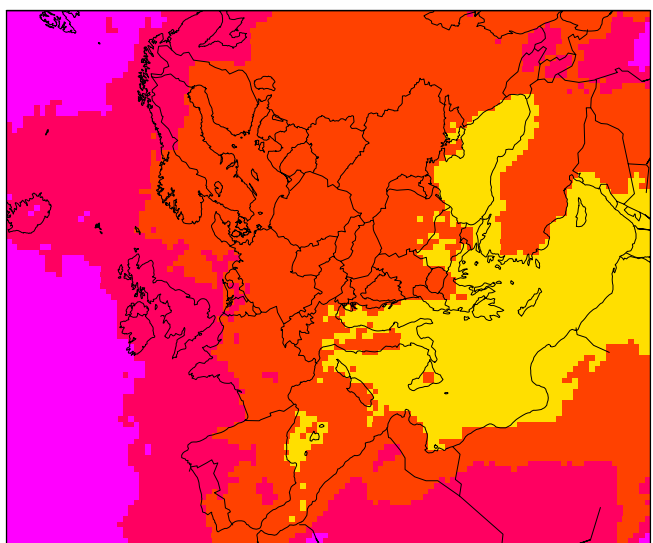

2002

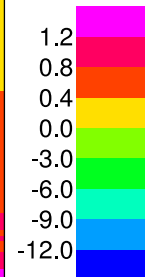

(c) Summer daily max. ozone (ppb), diff. Ref.-avgBC

Fig. 4. Summer (June, July, August) mean of daily ozone maxima in ppb. Top, summer ozone as calculated for 2002. Middle, difference in summer ozone calculated for the meteorological year 2002 with emissions for 2002 compared to emissions for 1990. Bottom, difference in summer ozone calculated for the meteorological year 2002 with 10 year (AvgBC) boundary conditions.

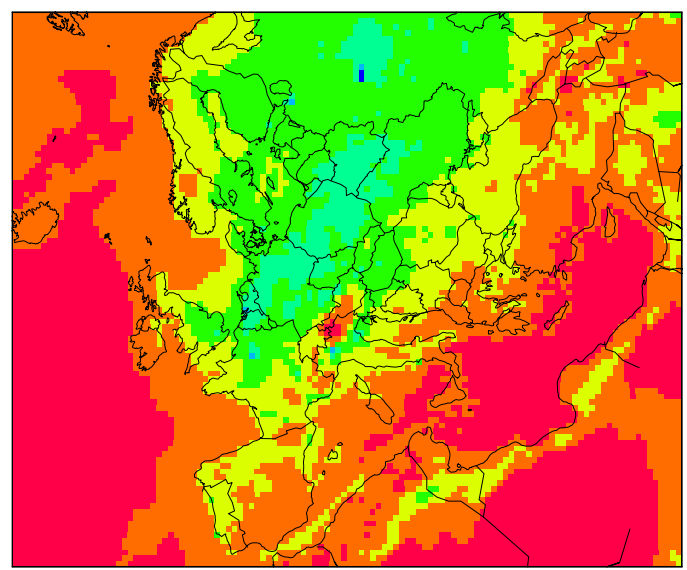

(a) Winter (January, February) daily max. ozone (ppb)

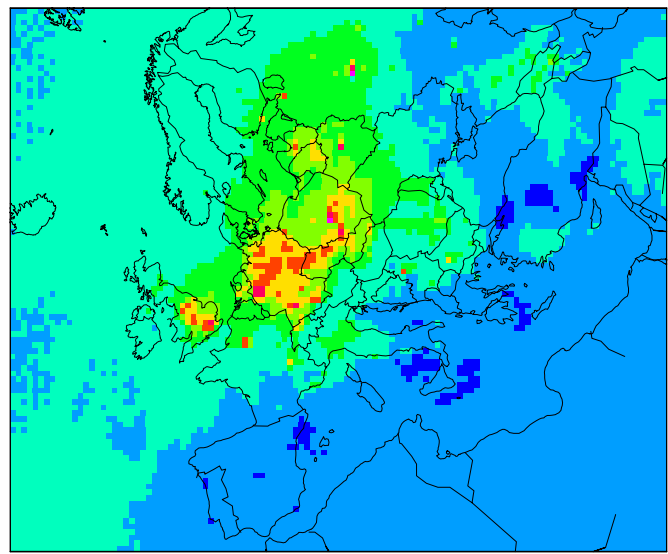

(b) Winter daily max. ozone (ppb), diff. Ref2002-Em1990

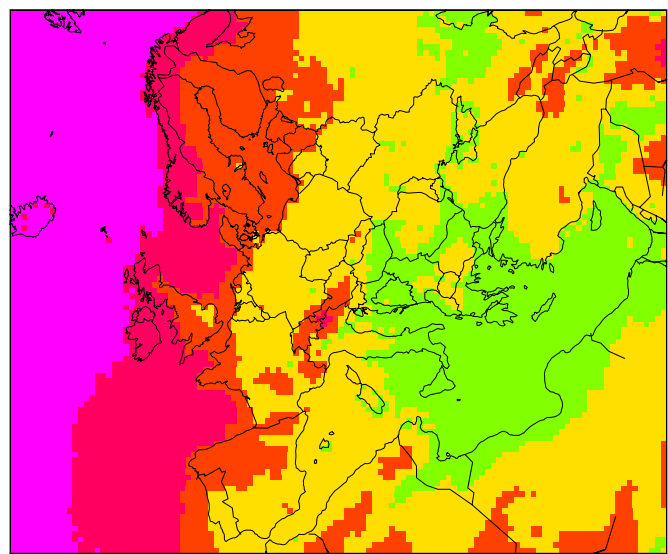

2002

(c) Winter daily max. ozone (ppb), diff. Ref.-avgBC

Fig. 5. Winter (January, February) mean of daily ozone maxima in ppb. Top, Winter ozone as calculated for 2002. Middle, difference in winter ozone calculated for the meteorological year 2002 with emissions for 2002-1990. Bottom, difference in winter ozone calculated with meteorological year 2002 with 10 year (AvgBC) boundary conditions.

\subsubsection{Em1990 scenario: effects on high ozone events}

The highest ozone events, here defined as the 7 highest ozone days in the year, are shown in Fig. 6a. High ozone events are 


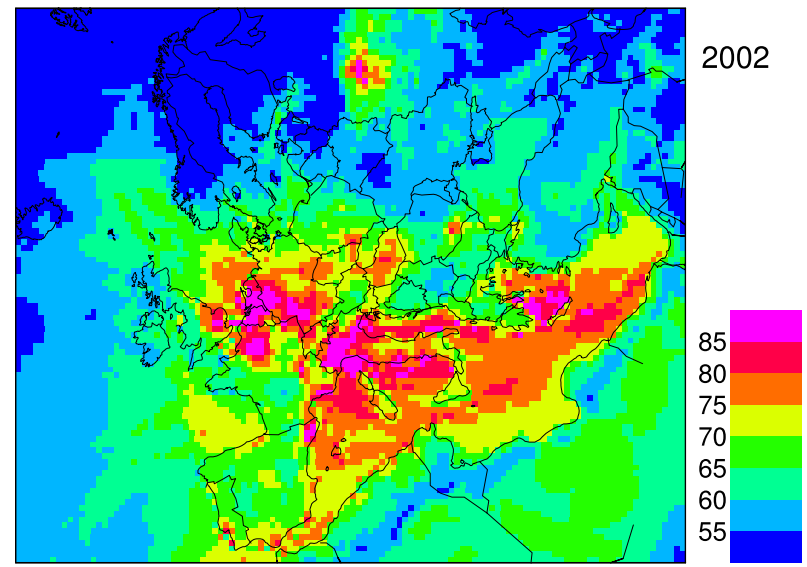

(a) Highest ozone (ppb) events

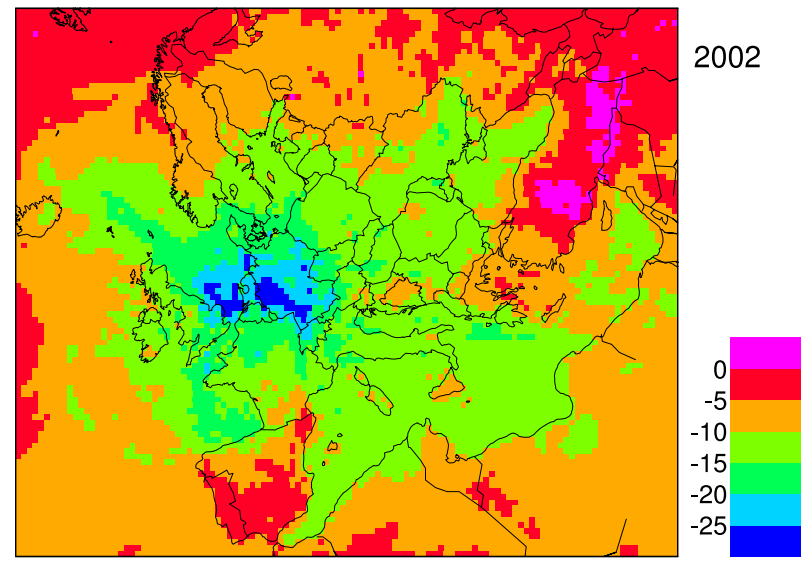

(b) High ozone (ppb), diff. Ref2002-Em1990

Fig. 6. High ozone events (average for 7 highest days in the year) in ppb. Top, average for year 2002. Bottom, difference in high ozone calculated for the meteorological year 2002 with emissions for the years 2002-1990.

in particular seen in the model calculations in and around the European countries with a Mediterranean coastline, in the countries around the English channel, and in parts of Germany. High ozone events are also apparent in the Moscow area. As a result of emission changes from 1990 to 2002 the calculated magnitude of the highest ozone events has been reduced by $10 \mathrm{ppb}$ or more in large parts of Europe (Fig. 6b). In parts of west and central Europe the magnitude has been reduced by as much as $25 \mathrm{ppb}$. As discussed in Sect. 4.2, changes of this order of magnitude are consistent with downward trends of measured high ozone percentiles.

\subsubsection{AvgBC scenario: importance of boundary conditions}

As discussed in Sect. 5.2, the standard boundary conditions (BCs) for the EMEP model consist of the 3-D dataset of Logan (1999), modified by a correction procedure based upon monthly clean-sector $\mathrm{O}_{3}$ measured at Mace Head in Ireland. The Mace Head correction accounts for trends and inter- annual variability in background ozone. For the AvgBC scenarios, model runs have also been made with the 10 -year average of monthly BCs (We can note that for 2002 the "Ref" correction is markedly higher than the 10 years average). Lateral boundary concentrations used in the AvgBC scenario represent concentrations in the middle of the 12 year period considered. In order to compare the effects of changes in BCs to changes in emission changes between 1990 and 2002 the changes found in this scenario should be multiplied by roughly a factor of two.

Differences between model runs with the Ref2002 and AvgBC scenarios are depicted in Fig. 4c for the summer months (June, July, August), and in Fig. 5c for the winter months (January, February). In the Atlantic, just west of Ireland, calculated effects are $4 \mathrm{ppb}$ or more in winter and $1.2 \mathrm{ppb}$ or more in summer. Multiplied by two (as explained above) this is in good agreement with the observed trends in the clean sector at Mace Head as described in Sect. 4.1. This is as expected as the lateral boundary concentrations are tied to the measurements at this site.

In large parts of Europe differences between the Ref2002 and $\mathrm{AvgBC}$ scenarios are mostly in the 0.5 to $1 \mathrm{ppb}$ range. Calculated effects are however more pronounced in winter, with ozone levels increasing by $2-3 \mathrm{ppb}$. Over the British isles, western and northern parts of the European mainland, as well as mountainous regions such as the Alps and Pyrenees (with a strong influence from the free troposphere), the increase is even stronger. This is in agreement with the observed trends at mountain sites as discussed in Sect. 4.1. A large part of the increase in winter ozone indicated by model and measurements for the northern European ensemble (Fig. 3b) is likely caused by an increase in background ozone.

Over central parts of Europe such as Germany, changes in summertime ozone are rather low, so the model predicts that changes in BCs are less important than the changes in European emissions represented by the Em1990 scenario. In wintertime the effects of the AvgBC scenario are comparable to that of the Em1990 scenario over Germany (or actually greater when we multiply by a factor of two).

Over Italy, the AvgBC scenario is predicted to give a slight increase in summertime ozone $(\sim 0.4 \mathrm{ppb})$, which is a much smaller effect than that produced by the Em1990 scenario. In winter the increase due to the AvgBC scenario is greater, $\sim 3 \mathrm{ppb}$, and actually bigger than the effect of the Em1990 scenario.

\section{Do we understand the trends?}

There are a number of significant complications in analyzing the trends in $\mathrm{NO}_{2}$ and ozone over the 12 year period. It is hard to know how far measurements reflect real changes in ozone, and how far they reflect changes in measurement techniques and procedures. Therefore most focus 
has been placed on comparison with ensembles of sites, rather than with individual sites, since it has been shown that trend-analysis at any one site is very sensitive to instrument changes and other factors. Using ensembles we hope to have avoided the most extreme problems of this type. There are large interannual variations in $\mathrm{NO}_{2}$ and in ozone caused by meteorological factors. Calculated and measured trends might be biased by the use of only one year (1990) at the beginning of the period. There are however reasonable agreements between trends inferred from the transient 1990 to 2002 reference run and differences in $\mathrm{NO}_{2}$ and ozone from the sensitivity tests. Another problem is the robustness of ozone changes against emission change. In a model experiment reducing the anthropogenic emissions stepwise in Europe (Monks et al., 2003) it was demonstrated that the largest effects on mean ozone were seen when removing the last $20 \%$ of the ozone precursor emissions. Thus reductions in surface ozone caused by more moderate reductions in ozone precursors could easily be masked by inter-annual variability and/or a trend in background ozone.

Still, the model runs discussed above, as well as observations, strongly suggests that ozone is affected by a combination of changes in European emissions (mostly reductions) of ozone precursors and an increase in lateral boundary concentrations (BCs). The calculations made above with 1990 versus 2002 emissions, or using 10-year average BCs versus annually variable $\mathrm{BCs}$, illustrate that both European emissions and BCs have likely contributed significantly to the ozone trend over Europe.

In wintertime, the decrease in $\mathrm{NO}_{\mathrm{x}}$ emissions leads to higher $\mathrm{O}_{3}$ levels, as does the increase in BCs. The calculated effects on ozone of emission changes and the increase in lateral boundary concentrations are of similar magnitude in central Europe. In western and northern parts of Europe the calculated increase in winter ozone is mostly caused by the increase in lateral boundary concentrations.

In summertime the direction of the ozone change due to emissions is in general opposite to that of the BC change, with the emission reductions reducing ozone levels in most areas, whereas the increasing levels of BCs leads to higher ozone levels. According to the model calculations, reductions in the emissions of ozone precursors should have produced a marked downward trend in calculated summer ozone in central Europe, and in southern Germany in particular.

Unfortunately, many of the sites with long timeseries suitable for trend studies are located in northern and western parts of Europe where the calculated effects of the emission changes are small. At the same time these areas are the ones most affected by an increase in background ozone. Over the period studied here, the seasonal cycles in these regions are changing towards a background situation with ozone spring maxima and summer minima. These transitions from summer to spring maxima may be seen as an indication that these regions are becoming less controllable by European emissions.
Still, despite these difficulties, we find that for $\mathrm{NO}_{2}$ the modeled and observed trends agree remarkably well, especially for the Nordic countries and Germany. Some discrepancies were found for eastern Europe, but with only two sites it is hard to know how far these differences are due to model problems, or to the observations. It is also quite possible that emission changes in eastern Europe are less well described over this period than those in western and northern Europe, because of the large economic restructuring in that region. Strongest trends in all regions are found in the winter months, and this is discussed further below.

For ozone the modeled and observed trends are also remarkably similar, although here the picture is more complicated. Winter, summer and autumn trends are well reproduced at most sites. Spring-time trends are not so well reproduced. The largest problems in summertime were seen in the southern UK, where measured downward trends are larger than those predicted by the model. Problems were also found in Northern Italy, but with only one site we cannot put too much weight on this analysis. Trends in the nearby Swiss site were captured rather well. There could be a number of possible explanations for the discrepancies which were found. For example, it may be that reported emission changes are not correct over this time period, which would of course lead to incorrect model predictions. An alternative explanation could be that non-linearities in ozone production lead to some bias in the model predictions over the course of this decade. Further studies, possibly with finer-resolution models, could help to decide if the latter effect is important or not.

The reported emission data points to differences in trends depending on emission sector. As a result, reductions in $\mathrm{NO}_{\mathrm{x}}$ emissions have in general been less effective in summer than in winter, and modeled trends for $\mathrm{NO}_{2}$ differ depending on season. The measured and modeled concentrations of $\mathrm{NO}_{2}$ indicate that, compared to the annual mean trend, reductions are larger in winter and smaller, or even absent, in summer. Compared to a situation with uniform emission changes throughout the year this will result in less titration and subsequently higher ozone in the winter months, and more $\mathrm{NO}_{\mathrm{x}}$ and subsequently more ozone production in the summer months.

As it stands now the magnitude and origin of the global/hemispheric ozone trends are not completely understood. In addition to changes in the contribution from other continents and from wildfires, circulation patterns may have changed, altering the exchange across the tropopause and also the circulation within the troposphere itself. Such changes may also have been brought about by global change. Changes caused by European emission changes may to a large extent be viewed as superimposed on these changes.

Finally, we may conclude that the EMEP photo-oxidant model, driven by changes in the imposed global/hemispheric boundary conditions and European emission changes, seems to be able to reproduce the observed trends of $\mathrm{NO}_{2}$ and ozone 
rather well over much of Europe. In order to understand those discrepancies which still remain, more work would be needed to (a) evaluate the emissions changes over this period in greater detail, (b) make more use of evaluated measurement data, seasonally differentiated, and screened for the types of problems which complicate trend studies, and (c) perform model studies with finer resolution in order to minimize the effects of non-linearities on the model predictions (this would need fine-resolution emissions also, which are not currently available). All of these tasks are extremely difficult and time-consuming, but given the importance of trend analysis for air pollution control, further work in these areas is highly encouraged.

Acknowledgements. The authors thank $\mathrm{H}$. Klein for technical assistance and S. Dalsøren, University of Oslo, for valuable discussions on ozone trends. This work was supported by the Co-operative Programme for Monitoring and Evaluation of the Long-range Transmission of Air pollutants in Europe (EMEP) under UNECE. We also want to thank the reviewers for valuable contributions to the paper.

Edited by: F. J. Dentener

\section{References}

Andersson-Sköld, Y. and Simpson, D.: Comparison of the chemical schemes of the EMEP MSC-W and the IVL photochemical trajectory models, Atmos. Environ., 33, 1111-1129, 1999.

Beilke, S. and Wilson, R. R.: The ozone concentration in Germany since 1990 and prognoses for the future development (in German), Tech. rep., Immissionsshutz 5, 2000.

Berge, E. and Jakobsen, H. A.: A regional scale multi-layer model for the calculation of long-term transport and deposition of air pollution in Europe, Tellus, 50, 205-223, 1998.

Berntsen, T. K., Isaksen, I. S. A., Myhre, G., Fuglestvedt, J. S., Stordal, F., Larsen, T. A., Freckleton, R. S., and Shine, K.: Effects of anthropogenic emissions on tropospheric ozone and its radiative forcing, J. Geophys. Res., 102, 28 101-28 126, 1997.

Brönnimann, S., Buchmann, B., and Wanner, H.: Trends in nearsurface ozone concentrations in Switzerland: the 1990s, Atmos. Environ., 36, 2841-2852, 2002.

Creilson, J., Fishman, J., and Wozniak, A.: Intercontinental transport of tropospheric ozone: a study of its seasonal variability across the North Atlantic utilizing tropospheric ozone residuals and its relationship to the North Atlantic Ocillation, Atmos. Chem. Phys., 3, 2053-2066, 2003,

SRef-ID: 1680-7324/acp/2003-3-2053.

Davis, D., Grodzinski, G., Kasibhatla, P., Crawford, J., Chen, G., S.Liu, Brady, A., Thornton, D., Guan, H., and Sandholm, S.: Impact of ship emissions on marine boundary layer $\mathrm{NO}_{\mathrm{x}}$ and $\mathrm{SO}_{2}$ distributions over the Pacific basin, Geophys. Res. Lett., 28, 235238, 2001.

Dentener, F., Stevenson, D., Cofala, J., Mecchler, R., Amann, M., Bergamaschi, P., Raes, F., and Derwent, R.: The impact of air pollutant and methane emission controls on tropospheric ozone and radiative forcing: CDT calculations for the period 1990
2030, Atmos. Chem. Phys., 4, 1-68, 2004,

SRef-ID: 1680-7324/acp/2004-4-1.

Derwent, R., Jenkin, M., Saunders, S., Pilling, M., Simmonds, P., Passant, N., Dollard, G., Dumitrean, P., and Kent, A.: Photochemical ozone formation in north west Europe and its control, Atmos. Environ., 37, 1983-1991, 2003.

Derwent, R., Stevenson, D., Collins, W., and Johnson, C.: Intercontinental transport and the origins of the ozone observed at surface sites in Europe, Atmos. Environ., 38, 1891-1901, 2004.

Emberson, L., Ashmore, M., Cambridge, H., Simpson, D., and Tuovinen, J.: Modelling stomatal ozone flux across Europe, Environmental Pollution, 109, 403-414, 2000.

Emberson, L., Ashmore, M., Simpson, D., Tuovinen, J.-P., and Cambridge, H.: Modelling and mapping ozone deposition in Europe, Water, Air and Soil Pollution, 130, 577-582, 2001.

Endresen, Ø., Sørgård, E., Sundet, J., Dalsøren, S., Isaksen, I., Berglen, T., and Gravir, G.: Emission from international sea transport and environmental impact, J. Geophys. Res., 108, 4560, doi:10.1029/2002JD002898, 2003.

Fagerli, H., Simpson, D., and Tsyro, S.: Unified EMEP model: Updates, in: Transboundary acidification, eutrophication and ground level ozone in Europe, EMEP/MSC-W Status Report 1/2004, The Norwegian Meteorological Institute, Oslo, Norway, 2004.

Fuhrer, J., Skärby, L., and Ashmore, M.: Critical levels for ozone effects on vegetation in Europe, Environmental Pollution, 91106, 1997.

Fusco, A. and Logan, J. A.: Analysis of 1970-1995 trends in tropospheric ozone at Northern Hemisphere midlatitudes with the GEOS-CHEM model, J. Geophys. Res., 108, 4449, doi:10.1029/2002JD002742, 2003.

Hauglustaine, D. A. and Brasseur, G.: Evolution of tropospheric ozone under anthropogenic activities and associated radiative forcing of climate, J. Geophys. Res., 106, 32 337-32 360, 2001.

Honrath, R., Owen, R., Val Martin, M., Reid, J., Lapina, K., Fialho, P., Dziobak, M., Kneissl, J., and Westphal, D.: Regional and hemispheric impacts of anthropogenic and biomass burning emissions on summertime $\mathrm{CO}$ and $\mathrm{O}_{3}$ in the North Atlantic lower free troposphere, J. Geophys. Res., 109, D24310, doi:10.1029/2004JD005147, 2004.

Jonson, J., Bartnicki, J., Olendrzynski, K., Jokobsen, H., and Berge, E.: EMEP Eulerian model for atmospheric transport and deposition of nitrogen species over Europe, Environ. Poll., 102, 289298, 1998 .

Jonson, J., Kylling, A., Berntsen, T., Isaksen, I., Zerefos, C., and Kourtidis, K.: Chemical effects of UV fluctuations inferred from total ozone and tropospheric aerosol variations, J. Geophys. Res. 105, 14 561-14 574, 2000a.

Jonson, J., Tarrasón, L., and Sundet, J.: Model calculations of present and future levels of ozone and ozone precursors with a global and a regional model, Atmos. Environ., 35, 525-537, 2001.

Jonson, J. E., Tarrasón, L., and Bartnicki, J.: Effects of international shipping on European pollution levels, EMEP/MSC-W note 5/00, The Norwegian Meteorological Institute, Oslo, Norway, 2000b.

Kanter, H.-J., Scheel, H., James, T. T. P., Stohl, A., and Feldmann, H.: Atmospheric long-range transport and its impact on the tracegas distribution in the free troposphere over Central Europe (AT- 
MOFAST), in: Ozone: Proceedings of the Quadrennial Ozone Symposium, edited by: Zerefos, C. S., p. 849-850, University of Athens, Athens, Greece., 2004.

Karlsdottir, S., Isaksen, I., Myhre, G., and Berntsen, T.: Trend analysis of $\mathrm{O}_{3}$ and $\mathrm{CO}$ in the period 1980 1996; A 3-D model study, J. Geophys. Res., 105, 28 907-28 934, 2000.

Kuebler, J., Van den Berg, H., and Russel, A.: Long-term trends of primary and secondary pollutant concentrations in Switzerland and their response to emission controls and economic changes, Atmos. Environ., 35, 1351-1363, 2001.

Lelieveld, J. and Dentener, F.: What controls tropospheric ozone?, J. Geophys. Res., 105, 3531-3551, 2000.

Li, Q., Jacob, D., Bey, I., Palmer, P., Duncan, B., Field, B., Martin, R., Fiore, A., Yantosca, R., Parrish, D., Simmonds, P., and Oltmans, S.: Transatlantic transport of pollution and its effects on surface ozone in Europe and North America, J. Geophys. Res., 107, 4166, doi:10.1029/2001JD001422, 2002.

Logan, J.: Trends in the vertical distribution of ozone: An analysis of ozonesonde data, J. Geophys. Res., 99, 25 553-25 585, 1994.

Logan, J.: An analysis of ozonesonde data for the troposphere: Recommendations for testing 3-d models and development of a gridded climatology for tropospheric ozone, J. Geophys. Res., 104, 16 115-16 150, 1999.

Logan, J., Megretskaia, A., Miller, A., Tiao, G., Choi, D., Zhang, L., Stolarski, R., Labow, G., Hollandsworth, S., Bodeker, G., Claude, H., De Muer, D., Kerr, J., Tarasick, D., Oltmans, S., Johnson, B., Schmidlin, F., Staehelin, J., Viatte, P., and Uchino, O.: Trends in the vertical distribution of ozone: A comparison of two analyses of ozonesonde data, J. Geophys. Res., 104, $26373-$ 26399, 1999.

Løvblad, G., Tarrasón, L., Tørseth, K., and Dutchak, S.: EMEP assessment PART I: European perspective, URL: http://www. emep.int, The Norwegian Meteorological Institute, Oslo, Norway, 2004.

Monks, P., Richard, A., Dentener, F., Jonson, J., Lindskog, A., Roemer, M., Schuepbach, E., Friedli, T., and Solberg, S.: Tropospheric ozone and precursors, trends budgets and policy. TROTREP synthesis and and integration report, http://atmos. chem.le.ac.uk/trotrep, 2003.

Naja, M., Akimoto, H., and Staehlin, J.: Ozone in background and photochemically aged air over central Europe: Analysis of long term ozonesonde data from Hohenpeissenberg and Payerne, J. Geophys. Res., 108, 4063, doi:10.1029/2002JD002477, 2003.

NEGTAP: Transboundary air pollution: acidification, eutrophication and ground level ozone in the UK, URL: http://www.nbu.ac. uk/negtap/, National Expert Group on Transboundary Air Pollution, 2001.

Newchurch, M., Yang, E.-S., Cunnold, D., Reinsel, G., Zawodny, J., and Russel III, J.: Evidence for slowdown in stratospheric ozone loss: First stage in ozone recovery, J. Geophys. Res., 108, 4507, doi:10.1029/2003JD003471, 2003.

Newchurch, M., Yang, E.-S., Cunnold, D., Reinsel, G., Salawitch, R., Zawodny, J., Russel III, J., and McCormick, M.: First stage in ozone recovery, in: Ozone: Proceedings of the Quadrennial Ozone Symposium, edited by: Zerefos, C. S., p. 27-28, University of Athens, Athens, Greece, 2004.

Oltmans, S., Lefohn, A., Scheel, H., Harris, J., Levy, H., Galbally, I., Brunke, E.-G., Meyer, C., Lathrop, J., Johnson, B., Shadwick, D., Cuevas, E., Schmidlin, F., Tarasick, D., H.Claude, Kerr, J.,
Uchino, O., and Mohnen, V.: Trends in ozone in the troposphere, Geophys. Res. Lett., 25, 139-142, 1998.

Ordóñez, C., Mathis, H., Furger, M., and Prévôt, A.: Trends of ozone in central Europe at different altitudes, in: Ozone: Proceedings of the Quadrennial Ozone Symposium, edited by: Zerefos, C. S., p. 904-905, University of Athens, Athens, Greece, 2004.

Ordóñez, C., Mathis, H., Furger, M., Henne, S., Hülin, C., Staehelin, J., and Prévôt, A.: Changes of daily surface ozone maxima in Switzerland in all seasons from 1992 to 2002 and descussion of summer 2003, Atmos. Chem. Phys., 5, 1187-1203, 2005,

\section{SRef-ID: 1680-7324/acp/2005-5-1187.}

Palmgren, F., Hansen, A., Berkowics, R., and Skov, H.: Benzene emissions from the actual car fleet in relation to petrol composition in Denmark, Atmos. Environ., 35, 35-42, 2001.

Pavelin, E., Johnson, C., Rughooputh, S., and Toumii, R.: Evaluation of pre-industrial surface ozone measurements made using Schönbein method., Atmos. Environ., 33, 919-929, 1999.

Roemer, M.: Trends of ozone and precursors in Europe. Status report TOR-2, TNO report r2001/244, TNO, 2001a.

Roemer, M.: In search for trends of ozone and precursors. First progress report TROTREP, TNO report r2001/100, TNO, 2001b.

Roemer, M., Beekmann, M., Bergström, R., Boersen, G., Feldmann, H., Flatøy, F., Honore, C., Langner, J., Jonson, J., Matthijsen, J., Memmesheimer, M., Simpson, D., Smeets, P., Solberg, S., Stern, R., Stevenson, D., Zandveld, P., and Zlatev, Z.: Ozone trends according to ten dispersion models, Special report, EUROTRAC-2, 2003.

Schuepbach, E., Friedli, T. K., Zanis, P., Monks, P., and Penkett, S.: State space analysis of changing seasonal ozone cycles (198897) at Jungfraujoch (3.580 m a.s.1.) in Switzerland, J. Geophys. Res., 106, 20 413-20 427, 2001.

Simmonds, P., Derwent, R., Manning, A., and Spain, G.: Significant growth in surface ozone at Mace Head, Ireland 1987-2003, Atmos. Environ., 38, 4769-4778, 2004.

Simmonds, P., Manning, A., Derwent, R., Ciais, P., Ramonet, M., Kazan, V., and Ryall, D.: A burning question. Can recent growth rate anomalies in the greeenhouse gases be attributed to largescale burning events?, Atmos. Environ., 39, 2513-2517, 2005.

Simpson, D.: Biogenic emissions in Europe 2: Implications for ozone control strategies, J. Geophys. Res., 100, 22 891-22 906, 1995.

Simpson, D., Andersson-Sköld, Y., and Jenkin, M. E.: Updating the chemical scheme for the EMEP MSC-W oxidant model : current status, EMEP MSC-W Note 2/93, The Norwegian Meteorological Institute, Oslo, Norway, 1993.

Simpson, D., Tuovinen, J.-P., Emberson, L., and Ashmore, M.: Characteristics of an ozone deposition module, Water, Air and Soil Pollution, Focus, 1, 253-262, 2001.

Simpson, D., Fagerli, H., Jonson, J., Tsyro, S., Wind, P., and Tuovinen, J.-P.: Transboundary acidification, eutrophication and ground level ozone in Europe, PART 1, Status report 1/2003, The Norwegian Meteorological Institute, Oslo, Norway, 2003a.

Simpson, D., Tuovinen, J.-P., Emberson, L., and Ashmore, M.: Characteristics of an ozone deposition module II: sensitivity analysis, Water, Air and Soil Pollution, 143, 123-137, 2003b.

Solberg, S.: Monitoring of boundary layer ozone in Norway from 1977 to 2002, TOR 85/2003, NILU, Norwegian Institute for Air Research, 2003. 
Solberg, S.: VOC measurements 2002, Tech. Rep. EMEP/CCC 8/2004 URL: http://www.nilu.no/projects/ccc/reports/ cccr08-2004.pdf, NILU, Norwegian Institute for Air Research, 2004

Solberg, S., Simpson, D., Jonson, J., Hjellberekke, A., and Derwent, R.: Ozone, in: EMEP assessment PART I: European perspective, edited by: Løvblad, G., Tarrasón, L., Tørseth, K., and Dutchak, S., Tech. rep., The Norwegian Meteorological Institute, Oslo, Norway, 2004

Solberg, S., Bergström, R., Langner, J., Laurila, T., and Lindskog, A.: Changes in Nordic surface ozone episodes due to European emission reductions in the 1990s, Atmos. Environ., 39, 179-192, 2005

Staehelin, J., Thudium, J., Buehler, R., Volz-Thomas, A., and Graber, W.: Trends in surface ozone concentrations at Arosa (Switzerland), Atmos. Environ., 28, 75-87, 1994.

Stocks, B., Mason, J., Todd, J., Bosch, E., Watson, B., Amino, B., Flannigan, M., Hirsch, K., Logan, D., Martell, D., and Skinner, W.: Large forest fires in Canada, 1959-1997, J. Geophys. Res., 108, 8149-8170, 2003.

Streets, D., Bond, T., Carmichael, G. R., Fernandes, S. D., Fu, Q., He, D., Klimont, Z., Nelson, S. M., Tsai, N. Y., Wang, M. Q., Woo, J.-H., and Yarber, K. F.: An inventory of gaseous and primary aerosol emissions in Asia in the year 2000, J. Geophys. Res., 108, 8809, doi:10.1029/2002JD003093, 2003.

Tarasova, O., Kuznetsov, G., and Nam, M.: The impact of the transport pattern changes on the surface ozone variability in Europe, in: Ozone: Proceedings of the Quadrennial Ozone Symposium, edited by: Zerefos, C. S., p. 193-194, University of Athens, Athens, Greece, 2004.

Thijsse, T., Roemer, M., and van Oss, R.: Trends in large-scale VOC concentrations in the Southern Netherlands between 1991 and 1997, Atmos. Environ., 33, 3803-3812, 1999.

TOR-2: Tropospheric ozone research, EUROTRAC-2 subproject final report, ISS GSF National Research Center for Environment and Health, Munich, Germany, 2003.
Tuovinen, J.-P., Simpson, D., Mikkelsen, T., Emberson, L., M., M. R. A., Aurela, Cambridge, H. M., Hovmand, M. F., Jensen, N. O., Laurila, T., Pilegaard, K., and Ro-Poulsen, H.: Comparisons of measured and modelled ozone deposition to forests in Northern Europe, Water, Air and Soil Pollution, Focus, 1, 263-274, 2001.

Tuovinen, J.-P., Ashmore, M., Emberson, L., and Simpson, D.: Testing and improving the EMEP ozone deposition module, Atmos. Environ., 38, 2373-2385, 2004.

UNECE: Present state of emission data, EB.AIR/GE.1/2004/10, United Nations, Economic and Social Council http://www.unece. org/env/emep/emep28_docs.htm, 2004.

Verwer, J. and Simpson, D.: Explicit methods for stiff ODEs from atmospheric chemistry, Appl. Numerical Mathematics, 18, 413430, 1995.

Vestreng, V., Adams, M., and Goodwin, J.: Inventory review 2004 Emission data reported to CLRTAP and under the NEC directive, EMEP/MSC-W status report 1/04, The Norwegian Meteorological Institute, Oslo, Norway, 2004

Volz, A. and Kley, D.: Evaluation of the Montsouris series of ozone measurements made in the nineteenth century, Nature, 332, 218 $219,1988$.

von Glasow, R., Lawrence, M., Sander, R., and Crutzen, P.: Modeling the chemical effects of ship exhaust in the cloud-free marine boundary layer, Atmos. Chem. Phys., 3, 233-250, 2003,

SRef-ID: 1680-7324/acp/2003-3-233.

WMO: Scientific assessment of ozone depletion: 2002, Report no. 47, World Meteorological Organization. Global Ozone Research and Monitoring Project, 2002.

Zbinden, R., Cammas, J., Thouret, V., Nedelec, P., Karcher, F., and Simon, P.: Mid-latitude tropospheric ozone columns from the MOZAIC program: climatology and interannual variability, Atmos. Chem. Phys. Discuss., 5, 5489-5540, 2005.

SRef-ID: 1680-7375/acpd/2005-5-5489. 